\title{
Geospatial Based Approach for Enhancing Environment Sustainability of Srinagar city - A Study on Solid Waste Disposal
}

\author{
Shamim Ahmad Shah and Muzafar Ahmad Wani \\ Department of Geography and Regional Development, University of Kashmir, \\ Srinagar, India 190006 \\ shamimcrocus@gmail.com
}

\begin{abstract}
In today's world solid waste management is a major global urban environmental issue which leads to health and environmental risk by intensifying air pollution, ground water contamination, providing breeding ground for flies, rodents, and stray dogs. The improper solid waste disposal in urban center like Srinagar city has resulted in environmental deterioration and negative aesthetic value of this tourist destination. There is an increase in commercial, residential and infrastructure development due to the population growth and huge tourist flow which resulted in generation of huge amount of solid waste. This study was carried out with the aim to analyze the present solid waste management system of the city by delineating a suitable site for the disposal of urban solid waste using geospatial technology. Multicriteria analysis method has been employed, i.e. ground water, slope, Land use, and other sensitive areas etc. in determination of an appropriate dumping site for solid waste disposal. The study has successfully identified two potential sites in north and south of the city, which would lessen the burden on the existing waste disposal site and enhance the waste management process in the city. The results showed that geospatial technology can serve as an efficient way of employing and managing various data that can be utilized in locating more appropriate places for the disposal of solid waste.
\end{abstract}

Keywords: Environmental, Tourist Flow, Solid Waste, Multi-Criteria, Geographic Information System

\section{Introduction}

Municipal solid waste management is regarded as one of the major problems for city planners, administrators and researchers all over the world. The problem is especially severe in most cities of developing countries, where increased urbanization, poor planning, and lack of adequate resources contribute to the poor state of municipal solid waste management [1-4]. Rapid population growth and urbanization in developing countries have led to the generation of enormous quantities of municipal solid wastes and consequential environmental degradation. Safe and reliable disposal of municipal solid wastes and residues is an important component of integrated waste management. Open dumping of municipal solid waste, which is practiced by about three-fourth of the countries and territories in the world is a primitive stage of waste disposal [5]. The most common problems associated with improper management of solid waste include diseases transmission, fire hazards, odor nuisance, atmospheric and water pollution, aesthetic nuisance and economic losses [6]. The site selection study for a municipal landfill in most of the cases is a costly affair [7]. Regulations and public opposition can make siting municipal solid waste landfills difficult [8]. The successful siting of a 
sanitary landfill requires overcoming significant environmental and political obstacles. It depends on convincing decision-makers and the public that a sanitary landfill is needed because it is easiest and cheapest for waste disposal [9]. Siting decisions are governed by the pre-existing land use dynamics of the urban area as well as the nature of potential interactions of the landfill with the pre-existing environmental, geologic, hydrological, and socio-economic parameters of the area. Landfill facility siting is also ecologically significant as it has a large impact on the surrounding environment [10]. Landfills have been known to contaminate drinking water wells, groundwater aquifers and nearby streams. The ecological effects of any site proposal must be considered, as a site could have the potential to release chemicals into nearby waterways and tributaries via ground leaching, which could ultimately contaminate water, wetlands and fish habitat [11]. In the domain of the science of solid waste management, identification of landfill sites for solid waste disposal remains a critical management issue wherein the selection should be based on a number of considerations [12]. Shortage of land for waste disposal and inappropriate landfill site is one of the biggest problems in most of the large urban areas in the world which has its negative impact on human and environment. Therefore more efforts are needed to overcome this problem that leads different agencies and establishments to find common limitations to protect human and environment from these consequences [13]. Therefore it is essential to dispose the solid waste to a landfill without creating a hazard to public health [14]. The landfill site should not damage to the environment and the ecology of the surrounding area $[8,15]$. Management of municipal solid waste in urban centers is becoming more complex due to scarcity of land for disposal [16]. Most spatial decision problems are multi-criteria in nature [17]. In order to identify appropriate placement for a landfill site, a diverse range of criteria must be employed in a Geographic Information Systems (GIS) for analysis. It is important to take a holistic approach and incorporate criteria from the social, spatial, economic, political and ecological realms of the problem [18]. GIS technology is also effective in handling large amounts of complex geographic data and significantly aiding the facility siting process [19]. The ultimate aim of GIS is to support spatial decision making which has been structured into three major phases: Intelligence, Design and Choice, based on Simons model of decision making [20]. Multi-criteria Analysis (MCA) is a decision support technique where a decision is a choice between alternatives (such as alternative actions, land allocations, etc.). In Multi-Criteria Analysis (MCA), an attempt is made to combine a set of diverse criteria to achieve sound base for decision making for a specific aim.

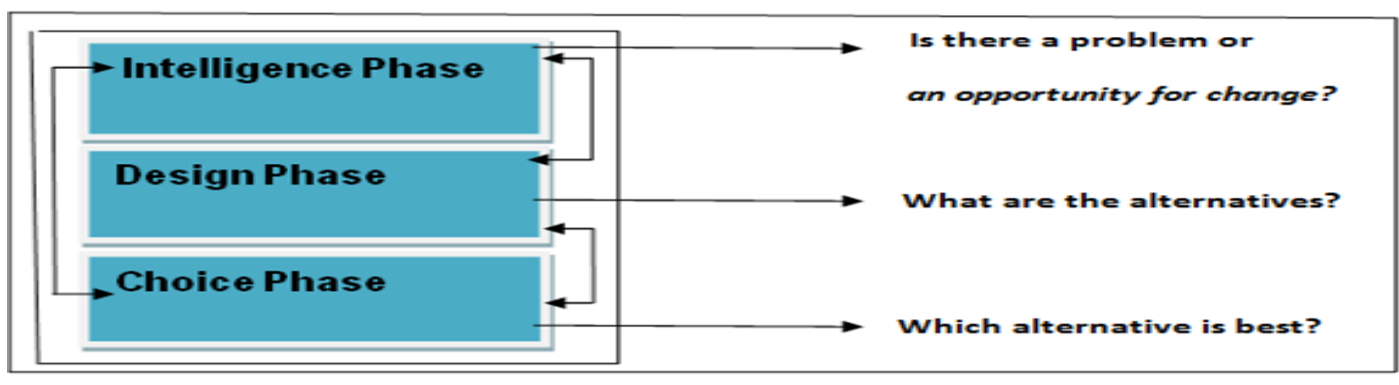

Figure 1. The Frame Work for Present Spatial Multi Criteria Analysis has Been Developed on the Simons Decision-Making Model. 


\section{Objective}

The major objective of the study is to select the suitable site for waste disposal based on multi-criteria analysis through Geographic Information System (GIS)

\section{Study Area}

The city lies on banks of the Jhelum River, a tributary of the Indus River. The area of the city is about $278.1 \mathrm{~km}^{2}$ with a population size of 1192792 [21]. The city is famous for its lakes, houseboats, gardens and shrines. Srinagar city has witnessed quick urbanization, but lack of commensurate investment in urban infrastructure and services has resulted in an overall deterioration of urban quality of life. Srinagar being the summer capital and an important tourist place is adversely affected by the lack of several infrastructure facilities. There is only one dump site in the city at Achan which has been selected without taking environmental consideration in to account. Moreover improper planning of urban management has significantly contributed to the deterioration of environment, threatens the quality of life of its dwellers and also affected tourism industry adversely. Srinagar city once called Venice of East is presently facing a serious problem in the form of improper solid waste disposal. As per report of Ministry of Urban Development government of India, Srinagar city was ranked as the fourth dirtiest among 423 cities of the India. The first three are noncapital cities making Srinagar the dirtiest capital city in entire country [22].

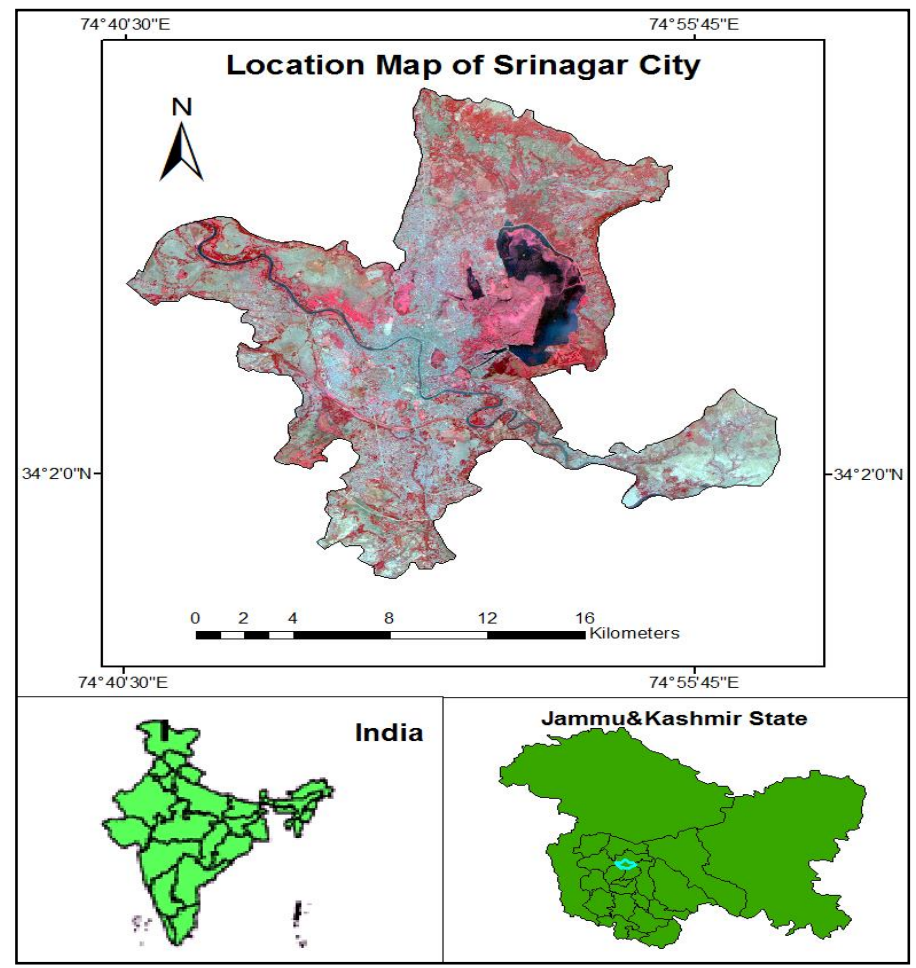

Figure 2. Study Area 


\section{Materials and Methods}

Information has been gathered using a variety of methods to gain a better understanding of the situation, issues and opportunities. First step was to identify criteria for sites selection. The criteria were derived from central pollution control board of India (CPCB) Municipal Solid Wastes (Management and Handling) Rules, 2000, and also through literature review of other works on landfill selection criteria [23, 24, 25 and 26]. The authors then modified the distance criteria after taking in to consideration geoecology of the area.

Table 1. Criterion for Selection of Suitable Landfill Site for Municipal Waste Dumping

\begin{tabular}{|l|l|l|}
\hline S.No & Criteria /layer & Preferred distance/ attributes \\
\hline 1 & Forest area & 2000 Meters \\
\hline 2 & Water body & 1000 Meters \\
\hline 3 & Wet land & 1000 Meters \\
\hline 4 & Plantation area & 1000 Meters \\
\hline 5 & Recreational area & 2000 Meters \\
\hline 6 & Built up & 1000 Meters \\
\hline 7 & Road net work & 500 Meters \\
\hline 9 & Airport & 2000 Meters \\
\hline 10 & Water Table & $\begin{array}{l}\text { Landfill should be an area where water table is } \\
\text { more than } 10 \text { meter below surface }\end{array}$ \\
\hline 11 & Slope & Slope should be less than 10 degrees \\
\hline
\end{tabular}

The second step was the acquisition data from various sources; therefore accordingly the remote sensing data of IRS-LISS III satellite imagery of spatial resolutions 23.5 meters year 2011, data of Central Ground Water Board Ministry of Water Resource Government of India (2005), survey of India toposheets covering the city (1971) and Carto Sat-1 imagery with 2.5 Meter spatial resolutions (2011) were collected. All these data sets were georefrenced and co-registered in ESRI's Eradas Imagine 9.2 versions and the study area was delineated. Subsequently ESRI's ARCGIS 10.1 were used to perform digital classification with the remote sensing data, with classes i.e. forest, plantation, wetland, water body, built up, airport etc. subsequently individual layers each class were developed. Further SRTM DEM was used for slope analysis. Similarly the toposheets and CARTO SAT-1 satellite imagery were used for developing road network. Besides that Global Positioning System (GPS) were used for tracking the location of waste collection points and dumper bins. In the last stage buffering technique were applied to develop Constraint mapping, and erase Technique was applied to search only those areas that are suitable for siting a landfill. Finally the suitable lands that were acquired through buffering and erase technique, which were overlaid with the ground water and slope to choose the best possible site. 


\section{Results and Discussion}

\subsection{Identification of Problem}

Srinagar city generate about 411 tons of solid waste per day as per the official reports. Quite often due to insufficient conservancy services in the city garbage is seen littered on the road sides, open spaces and is even dumped in water bodies leading to unhygienic living environment in the city. Dumpsites have been linked to many harmful health effects, including skin and eye infections, respiratory problems, vector-borne diseases such as diarrhea, dysentery, typhoid, hepatitis, cholera, malaria and yellow fever, high blood lead levels and exposure to heavy-metal poisoning [27]. Srinagar city has only one dumpsite which is located at Achan that has been in use since 1987. The site is situated in the North of the city and approximately 5-6 Kilometers, from the center of city. The solid waste of the entire city is being transported to the dump site from more than 518 collection points. The Projected Garbage generation by the year 2021 is estimated at 621 tons /Day [26]. The main settlements surrounding the dump site i.e., Saidapora, Shonglipora, Waganpora, Sangam, Braywar, Danmar, Guzerbal, Noor shah Colony and Bagh-i-Lal Pandith compliant that they have been affected with dumping of solid waste and demand immediate closure of the dump site. The present landfill site is highly unscientific not only in terms of crude dumping method but also from environmental and socio economic parameters.

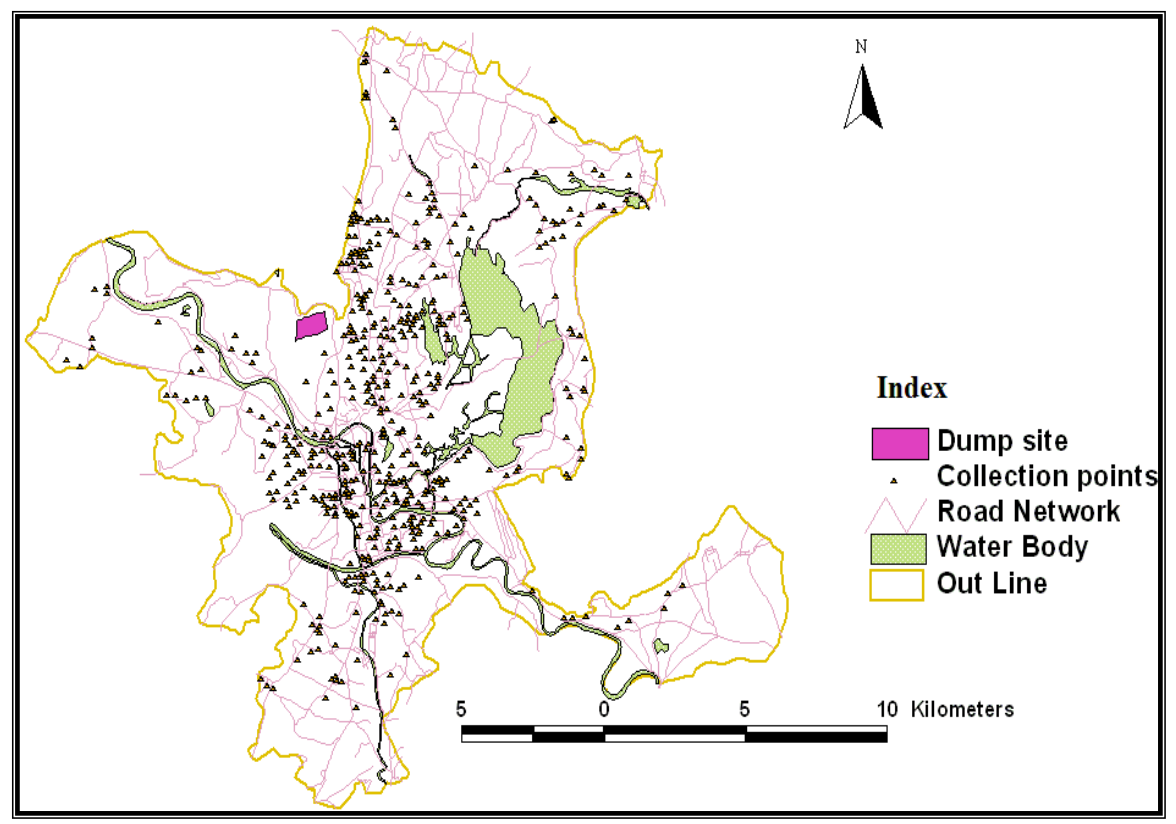

Figure 3. Existing Waste Collection and Disposal System in Srinagar City 
Table 2. Projected Waste Generation up to 2026 in Srinagar City

\begin{tabular}{|l|l|l|}
\hline Year & Projected Population & Total waste ton/day \\
\hline 2006 & 11,37125 & 335.00 \\
\hline 2011 & $12,99,924$ & 411.00 \\
\hline 2016 & $14,85,187$ & 506.00 \\
\hline 2021 & 17,04757 & 627.00 \\
\hline 2026 & 1949980 & 771.76 \\
\hline
\end{tabular}

Given the existing waste management scenario of the city, in the coming years there will be dramatic growth of population coupled with ever increasing immigration and tourist flow there is every possibility that city's natural environment will get tremendous havoc on account of improper solid waste disposal. Therefore it is inevitable to identify suitable dumping sites to ensure sustainable environmental management of the city.

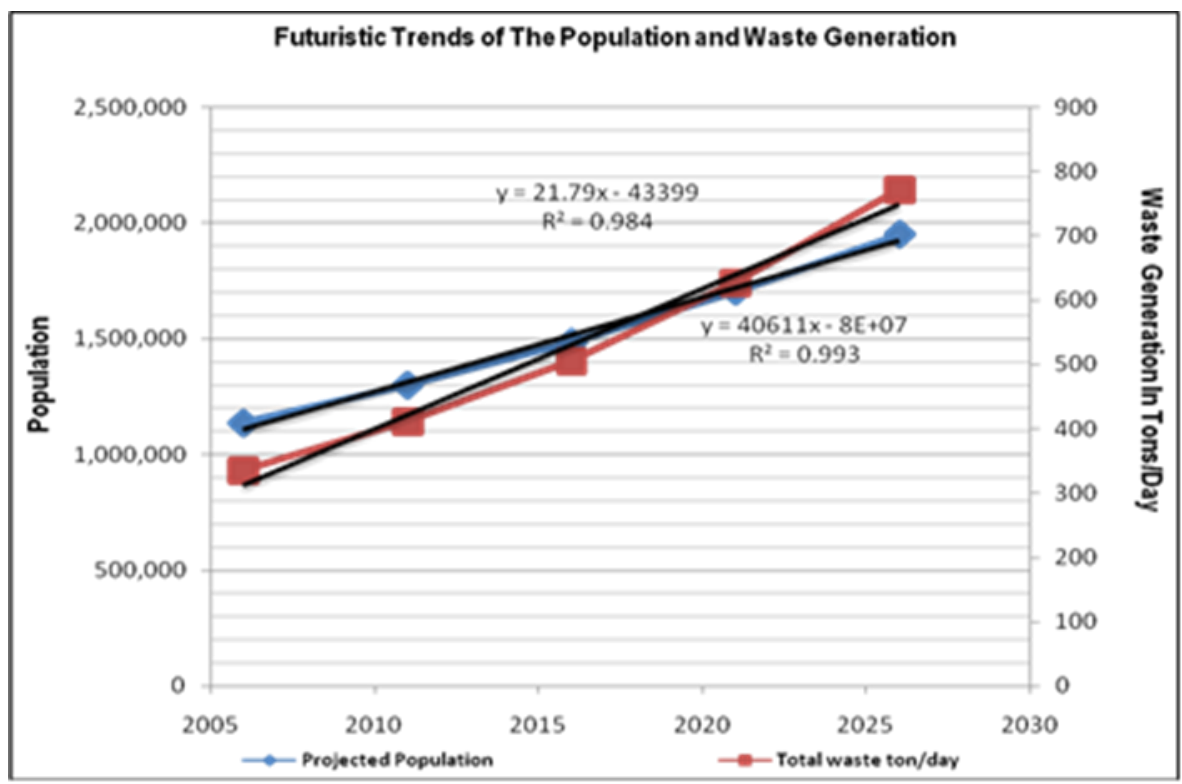

Figure 4. Future Trends of Waste Generation in Srinagar City 


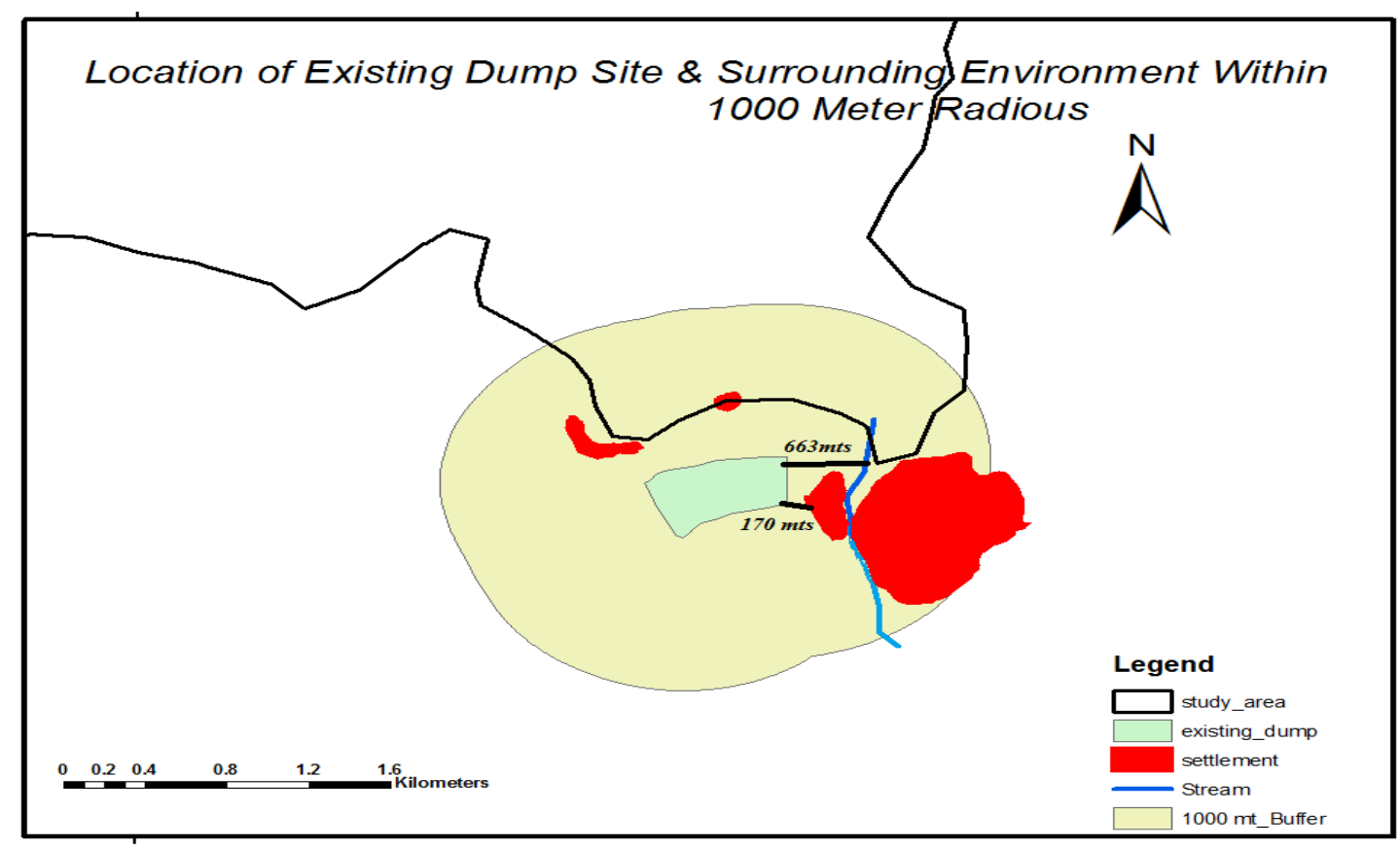

Figure 5. Crude Dumping of Garbage in Srinagar City

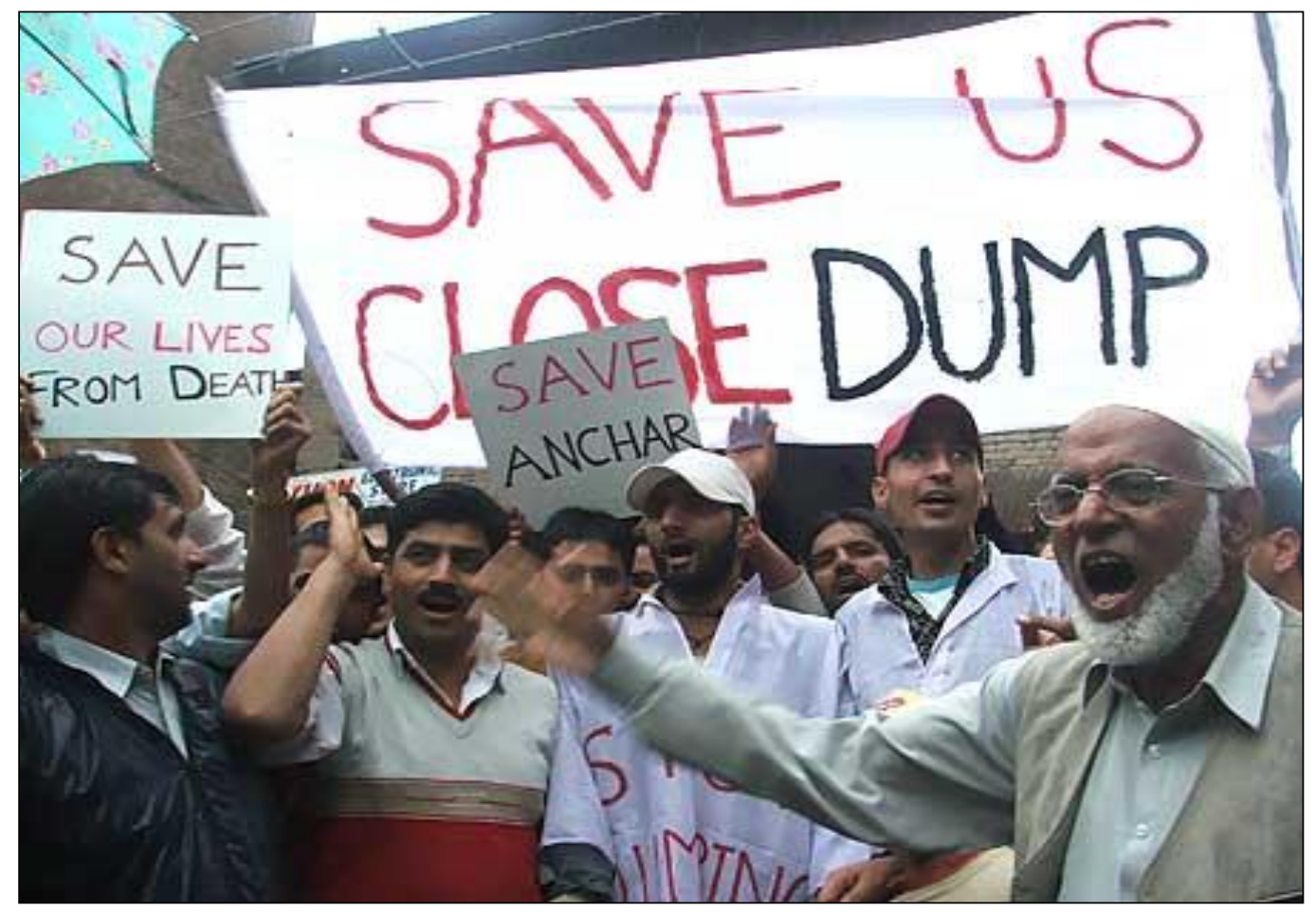

Figure 6. Violent Protest Seeking Immediate Closure of Achan Dump Site 


\subsection{Design Phase}

The design phase of a geographic information system (GIS) based planning process involves creating and analyzing a set of possible solutions to problem identified in the condition assessment phase or intelligence phase. Design phase involves inventing and analyzing a set of possible solutions to problem identified in the intelligence phase. So design phase represents the decision situation by structuring and formalizing the available data and information about the decision problem. Spatial decision alternatives are derived by manipulation and analysis of the data and information stored in geographic information system (GIS). The capabilities of geographical information system for evolving a set of alternative decisions are mainly based on spatial relationships principles of connectivity, contiguity, proximity and the overlay methods. During design phase various map layers were generated which help in suitability analysis for landfill site selection.

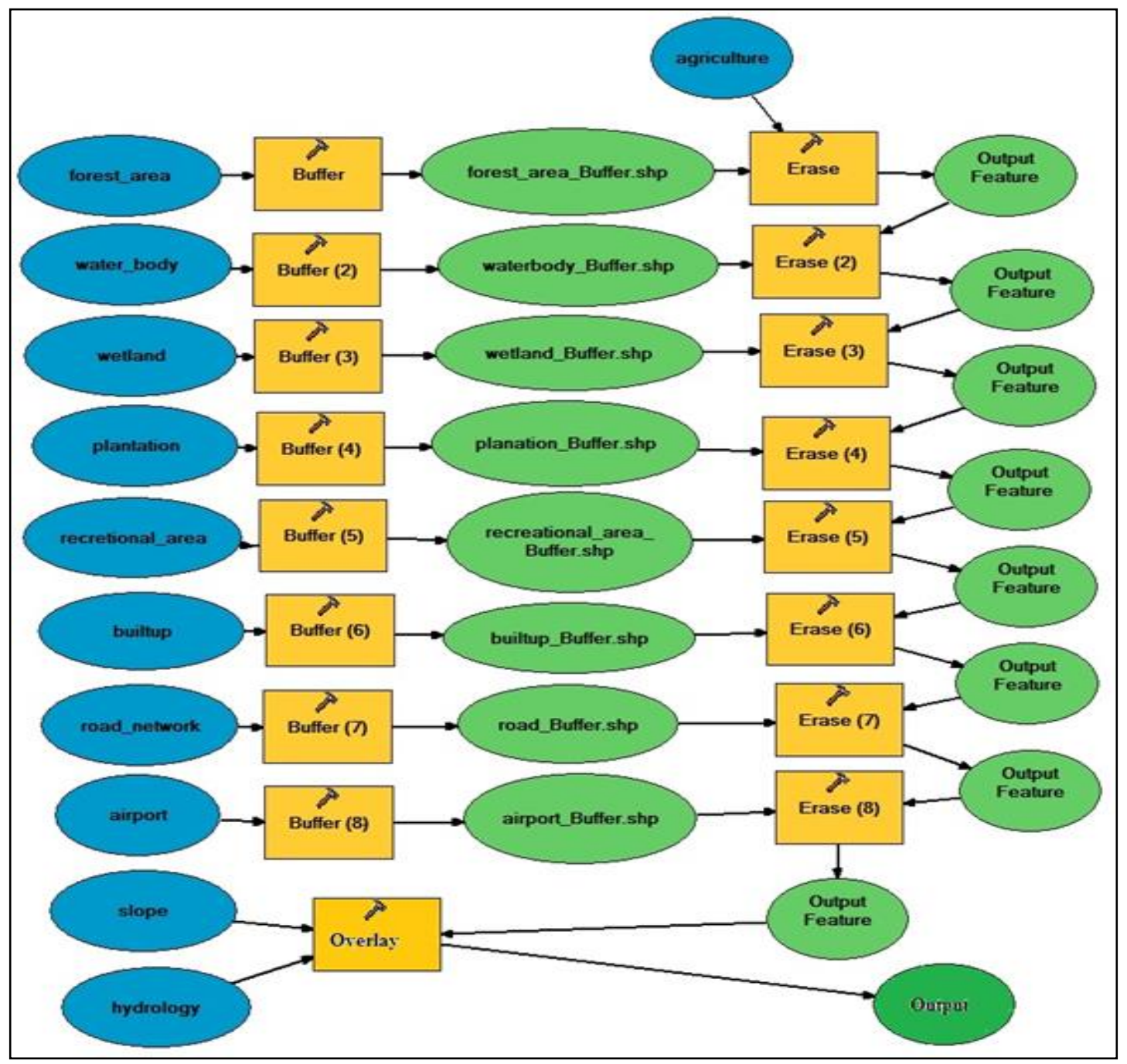

Figure 7. Flow Chart Showing Methodology Used in GIS Environment 


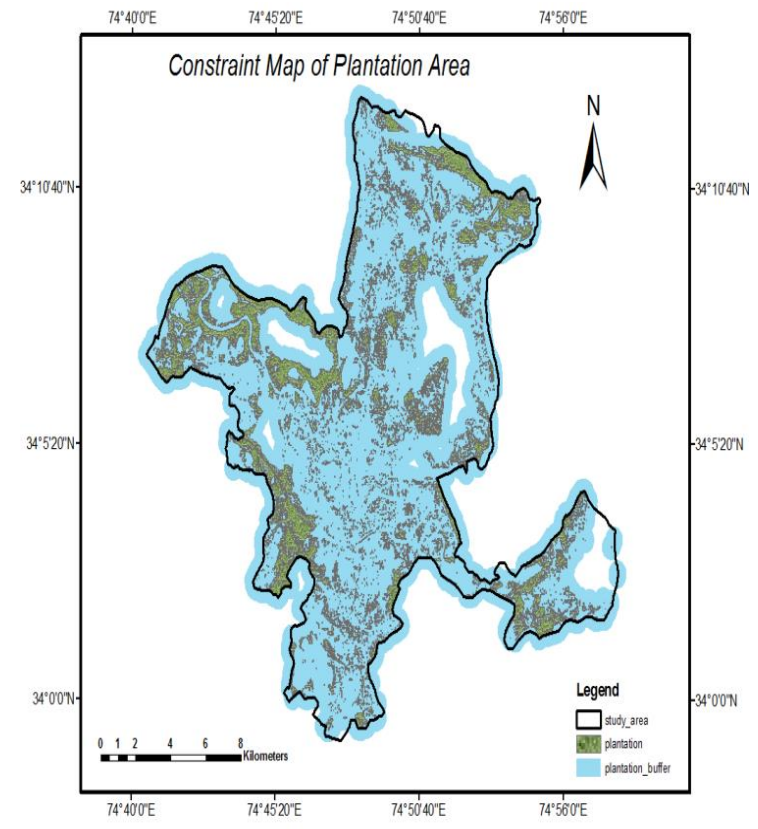

Figure. 8

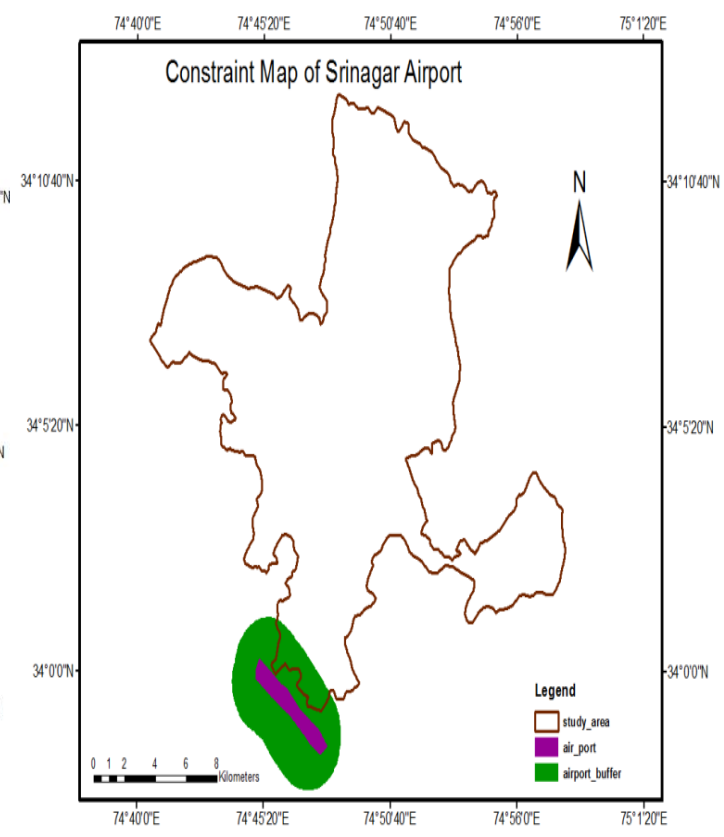

Figure. 9

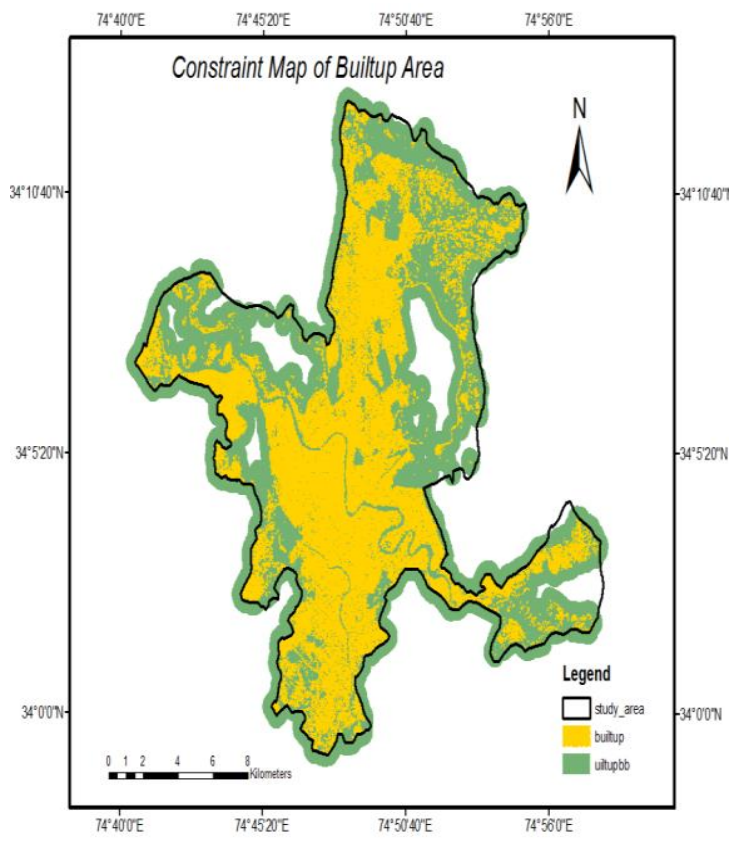

Figure. 10

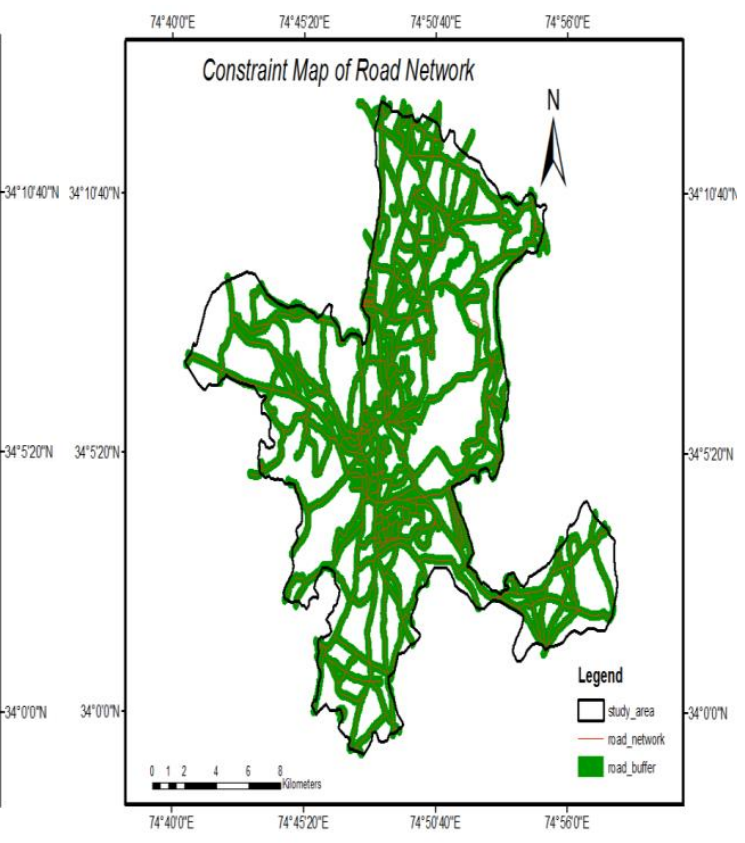

Figure. 11 
International Journal of $\mathrm{u}-$ and $\mathrm{e}-$ Service, Science and Technology

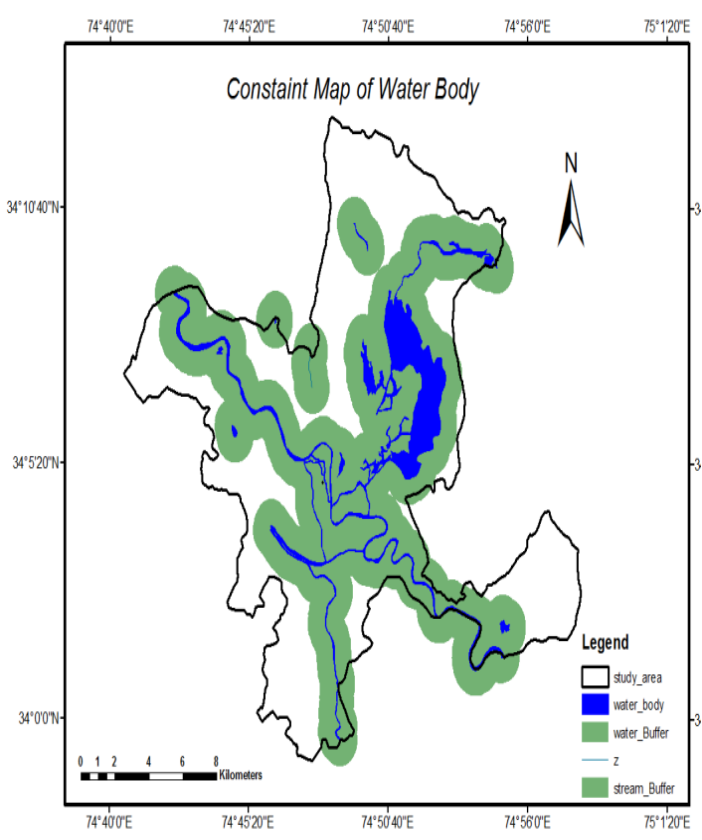

Figure. 12

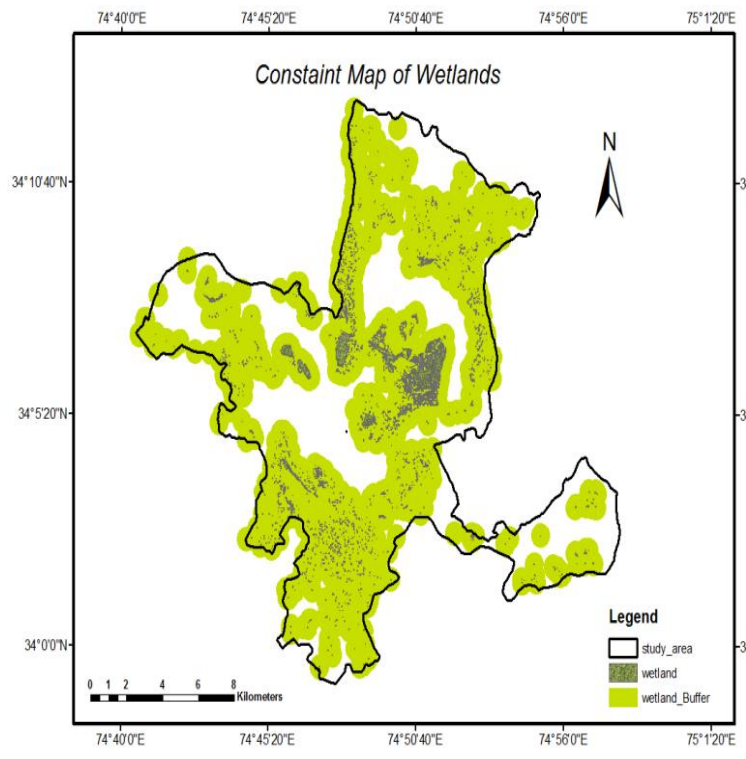

Figure. 15

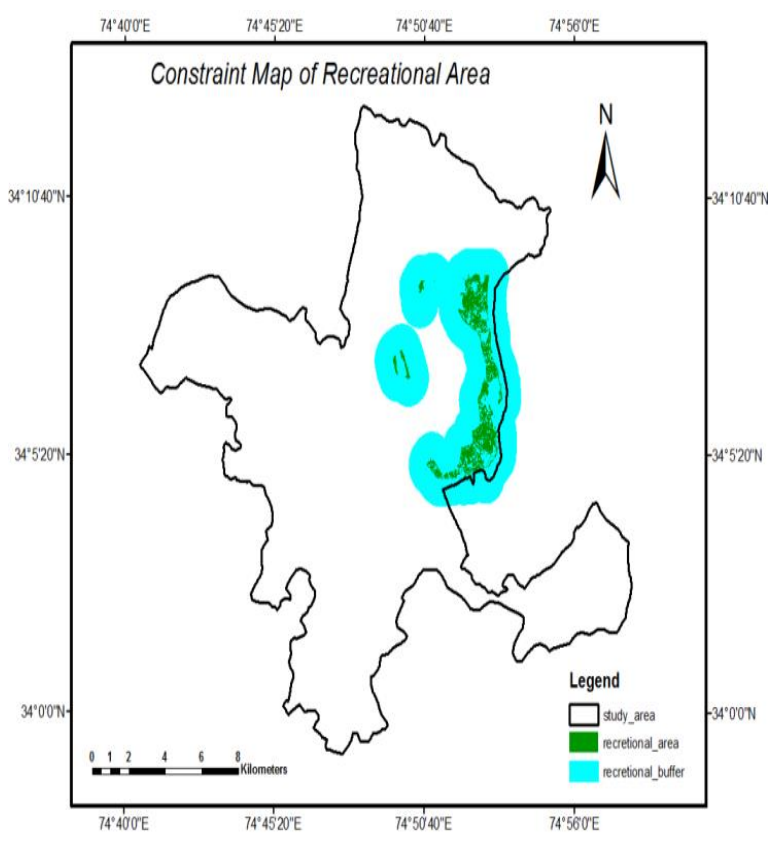

Figure. 13

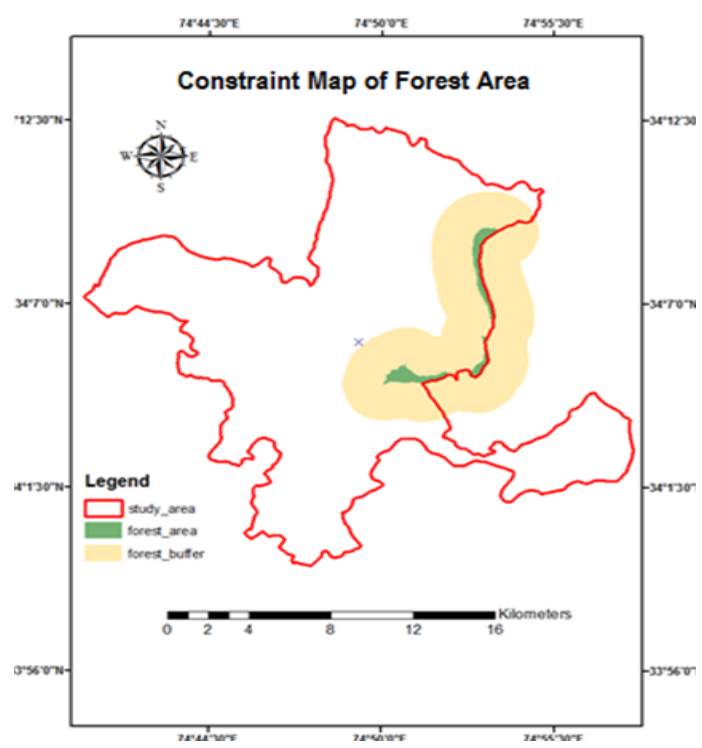

Figure. 14 


\subsection{Choice Phase}

Decision rules for locating suitable sites for solid waste disposal has been prepared in GIS environment based on multi criteria analysis process. In the choice phase each alternative is evaluated and analyzed in relation to others in terms of specific decision rule. Through the buffering and erase techniques three potential sites for waste dumping were identified and selection of the best one has to be made on the basis of slope and ground water depth. Subsequently After doing overlay analysis two sites are identified as considered suitable keeping in view slope and ground water depth owing to its geo ecological position of the city. Site-1 is considered highly suitable because its major areas lies in 0-5 degree slope and only few portions have 5-17 degree slopes. Besides that the site lies has 5-10 meter ground table water below surface, which would be considered ideal under the circumstances. Whiles as the site -2 is labeled as moderately suitable because its slope lies 5-17 degrees to 17- 36 degrees with moderately suitable water ground water table.

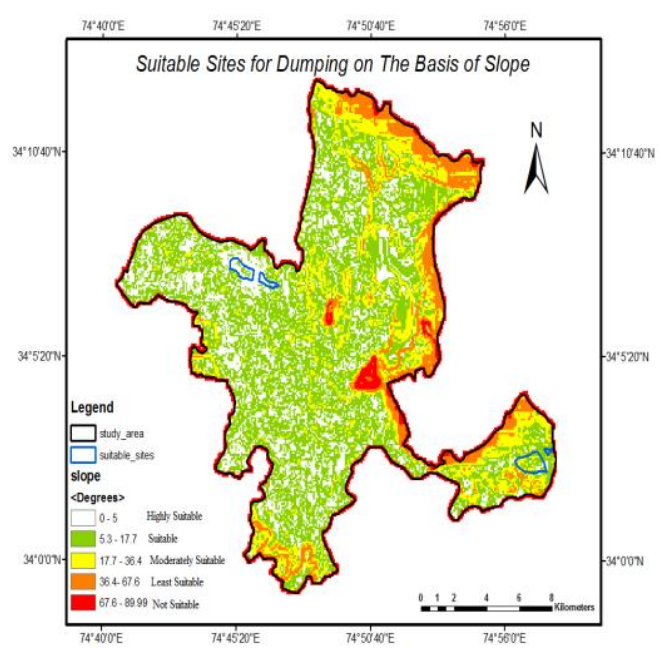

Figure. 16

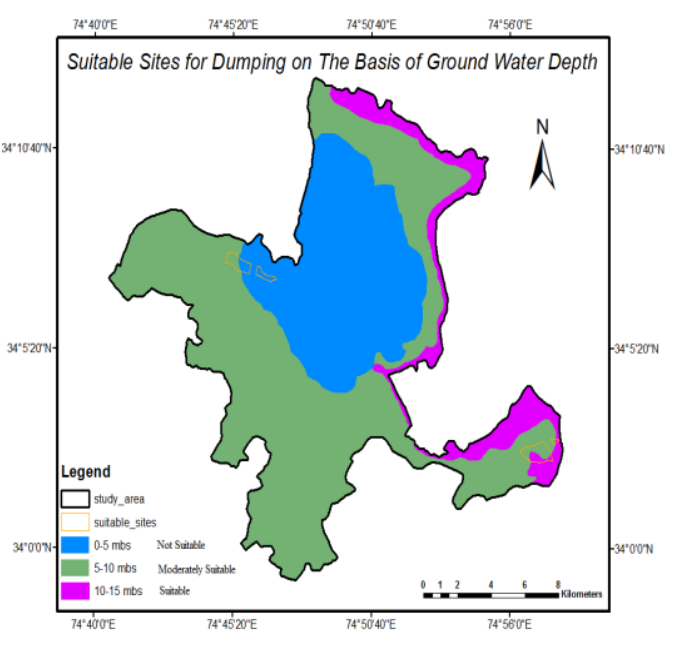

Figure. 17

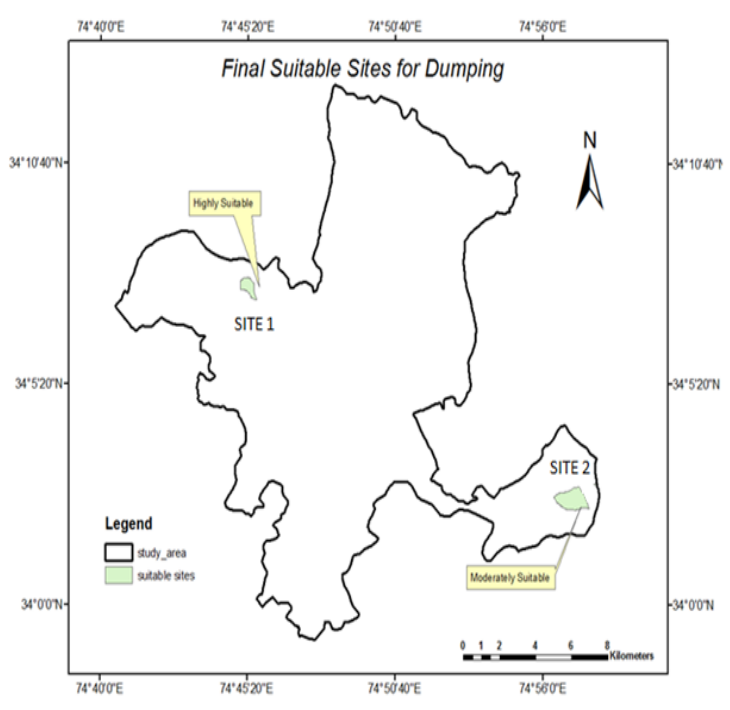

Figure. 18 


\section{Conclusion}

The socio-economic and environmental problems associated with the solid disposal site are complex because of the quantity and diverse nature of the wastes. Therefore, solid waste should be managed by modern technologies and methods that support long term sustainability of communities and environment. The study used integrated methodology through Geographic Information System (GIS) for the selection of sites, that are suitable for the disposal of solid waste. This methodology incorporates a large number of environmental and socio-economic parameters which are essential to identify the sites which have minimum adverse impact on environment. The study has successfully identified two potential sites in north and south of the city, which would lessen the burden on the existing waste disposal site and enhance the waste management process in the city. The study demonstrates the importance of GIS technology in solving emerging urban problems of cities. Geospatial technology, as an information tool, has helped in the generation of Information on different aspects like land use, road, and slope etc. Integration of different data sets in Geographic Information System (GIS) has resulted in multi-layer display of the data, which would have otherwise been difficult to do manually using the conventional method. Geographic information system (GIS) is highly sophisticated tool used for decision making process. The sustainable waste management will no longer be difficult for city administrators and planners.

\section{References}

[1] N. Obirih-Opareh, and J. Post, "Quality Assessment of Public and Private Modes of Solid Waste Collection in Accra, Ghana”, Habitat International, vol. 26, (2002), pp. 95-112.

[2] R .R .A. M. Mato, "Environmental Implications Involving the Establishment of Sanitary Landfills in Five Municipalities in Tanzania: the Case of Tanga Municipality", Resources, Conservation and Recycling, vol. 25, (1999), pp.1-16.

[3] P. L. Doan, "Institutionalizing Household Waste Collection: The Urban Environmental Management Project in Cote D'Ivoire, Habitat International, vol. 22, no.1, (1998), pp. 27-39.

[4] M. A. Mwanthi, L. O. Nyabola and E. D. Tenambergen, "The Present and Future Status of Municipal Solid Waste Management in Nairobi”, International Journal of Environmental Health Research, vol.7, (1997), pp. 345-353.

[5] P. E. Rushbrook, M. P. Pugh, "Solid Waste Landfills in Middle and Lower Income Countries: A Technical Guide to Planning, Design, and Operation”, World Bank, Washington, DC (2000).

[6] H. Basagaoglu, E. Celenk, M.A. Marino and N. Usul, "Selection of Waste Disposal Sites Using GIS, Journal of the American Water Resources Association, vol. 33, no. 2, (1997), pp. 455-463.

[7] L. E, Joyce, "How to Calculate Waste Disposal Costs", Government Finance Review, vol. 36, no. 3, (1990), pp. 20-21.

[8] M. Z. Siddiqui, J. W. Everett and B, E. Vieux, "Landfill Siting Using Geographic Information Systems: A Demonstration”, Journal of Environmental Engineering, vol. 122, no. 6, (1996), pp., 515-523.

[9] W. N. Lane, and R. McDonald, "Land Suitability Analysis: Landfill Siting, Journal of Environmental Engineering”, vol.109, no.1, (1993), pp. 50-61.

[10] N. Bodhankar, and B. Chatterjee, "Pollution of Limestone Aquifer Due to Urban Waste Disposal Around Raipur, Madhya Pradesh”, India, Environmental Geology, vol. 23, no. 1, (1994), pp. 209-213.

[11] B. B Nagar and U.K. Mizra, "Hydro Geological Environmental Assessment of Sanitary Landfill Project at Jammu City, India”, Electronic Green Journal, vol. 17, no. 8, (2002), pp.153-169.

[12] "Central Pollution Control Board Guidelines for the Selection of Site for Landfilling", Hazardous Waste Management Series, (2003), pp. 1-11.

[13] A. Markandya, and D. Pearce, "Development, the Environment and the Social Rate of Discount", World Bank Research Observer, vol. 6, no.2, (1991), pp. 137-52.

[14] A. Y1lmaz, and E. Atmaca, "Environmental Geological Assessment of a Solid Waste Disposal Site: A Case Study in Sivas, Turkey, Environmental Geology, vol. 50, (2006), pp. 677-689. 
[15] E. Erkut, S.R. Moran, "Locating Obnoxious Facilities in The Public Sector: An Application of The Hierarchy Process to Municipal Landfill Siting Decisions”, Socio - Economic Planning Sciences, vol. 25, no. 2, (1991), pp. 89-102.

[16] Babyrani and Bhoyar, "Feasibility of Some Treatments for Improving the Composting of Municipal Solid Waste", Indian Journal of Environmental Health, vol.45, no.3, (2003), pp.231-234.

[17] J. Malczewski, "GIS and Multicriteria Decision Analysis”, John Wiley \& Sons, New York, (1999), pp. 6-97.

[18] J. Kao and H. Lin, "Multi-factor Spatial Analysis for Landfill Siting", Journal of Environmental Engineering, vol. 122, no.10, (1996), pp.902-908.

[19] A. K. Dikshit, T. Padmavathi and R. K. Das, "Locating Potential Landfill Sites Using Geographic Information Systems", Journal of Environmental Systems, vol.28, no.1, (2000), pp. 43-54.

[20] "Simons Model of Decision Making", www.gsu/simonmodel.doc

[21] "Census (2011) Population of Srinagar city", www. census 2011.co.in.org.html

[22] Ministry of Urban Development, "Rank of Cities On Sanitaion", National Urban Sanitation Policy India, (2010), http://www.indiawaterportal.org

[23] Shamshiry, Nadi, Mokhtar, Komoo and Halimaton, "Urban Solid Waste Management Based on Geoinformatics Technology", Journal of Public Health and Epidemiology, vol.3, no.2, (2011), pp.54-60.

[24] S. Sener,, E. Sener and B. Nas, "Selection of Landfill Site using GIS and Multicriteria Decision Analysis for Beysehir Lake Catchment area Konya, Turkey”, Journal of Engineering Science and Design, vol.1, no.3, (2011), pp. 134-144.

[25] A. Babalola and I. Busu, "Selection of Landfill Sites for Solid Waste Treatment in Damaturu Town-Using GIS Techniques", Journal of Environmental Protection, vol. 2, (2011), pp. 1-10.

[26] ERA(Economic Reconstruction Agency), "Master Plan Report on Solid Waste Management of Srinagar", Multi -Sector Project Submitted By Project Management Consultants 4C/C Gandhi Nagar Jammu India, (2007).

[27] UNEP, "Towards a Green Economy: Pathways to Sustainable Development and Poverty Eradication", United Nations Environment Programme, (2011).

\section{Authors}

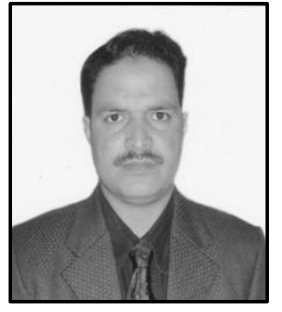

Shamim Ahmad Shah, is an Associate Professor in the Department of Geography and Regional Development at University of Kashmir (India) He has received his Ph.D Degree from Jamia Millia Islamia (central university) New Delhi, India. He is actively engaged in research and teaching of travel and tourism, environment planning, GIS and Remote sensing application for problem solving. He is presently guiding four Ph.D. research scholars, besides he is also running a major research project sanctioned by UGC (University grants commission of India) on solid waste management for Leh town of Ladakh India. He has widely participated and presented research papers in national and international conferences and seminars.

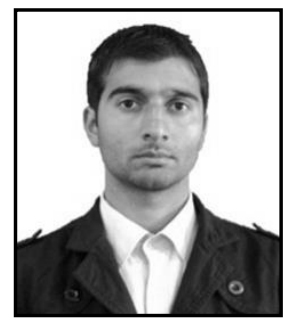

Muzafar Ahmad Wani, is presently pursuing his doctorate from Department of Geography and Regional Development at University of Kashmir (India) with specialization in sustainable environmental planning, in addition he is working as JRF for a UGC (University Grants commission of India) funded Major research project on solid waste management for Leh town of Ladakh India. He has received master's degree in geography in 2009 and M.Phil. in 2012 from the same university. He also qualified UUC NET examination in April 2013. He has also done advanced training course in remote sensing and GIS applications from NRSC (ISRO) Hyderabad India. He has also published five research paper in reputed international journals. 
International Journal of $u$ - and e- Service, Science and Technology Vol.7, No.3 (2014) 